\title{
The Impact of the SARS-CoV-2 (COVID-19) Pandemic on Gastroenterology Training
}

\author{
Anthea Pisani $^{\mathrm{a}} \quad$ Isabelle Cremers ${ }^{\mathrm{b}}$ Pierre Ellul ${ }^{\mathrm{a}}$

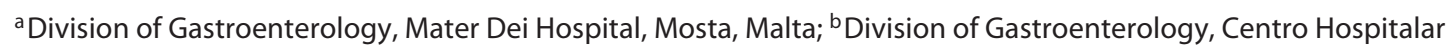 \\ de Setúbal, Setúbal, Portugal
}

Keywords

COVID-19 pandemic · Training · Endoscopy

\section{Abstract}

Introduction: The SARS-CoV-2 (COVID-19) pandemic has brought about a radical change in our working patterns. These changes can affect the training that gastroenterology trainees undergo, especially endoscopy since these are aerosol-generating procedures. The aim of this survey was to assess the effect of the COVID-19 pandemic on gastroenterology training across the European countries. Methodology: A questionnaire was set up whereby the different elements of training were analysed. The questionnaire (online) was distributed among trainees through the National Representatives of the European Board of Gastroenterology and Hepatology. Results: In total, 86 trainees (females: $55 \%$; mean age: 32.5 years [SD \pm 4.57 years]; mean training duration of 2.68 years [SD \pm 1.63$]$ ) from 22 different countries were recruited. From the cohort, $10.5 \%$ were considered as vulnerable for acquiring COVID-19. During their job, $4.7 \%$ acquired the infection and $26.7 \%$ were placed in quarantine. Most trainees noted that their various aspects of gastroenterology training were moderately or severely affected during the initial height of the pandemic: clinical gastroenterology training (67.4\%), outpatients (75.5\%), didactic teaching (88.3\%), multidisciplinary team meetings (65.2\%) and endoscopy training $(75.6 \%)$. Later, when the number of COVID-19-related infections decreased across Europe, the above modalities returned to normal for $<50 \%$ of the trainees. Conclusion: This European-wide survey has demonstrated that gastroenterology training has been severely impacted during both the initial height of the pandemic and afterwards. Furthermore, the psychological impact on trainees, in terms of training quality, duration and exposure to COVID-19, is unknown. A re-assessment of each centre training programme should be done as to ensure that a high standard of training is still being delivered.

(C) 2021 Sociedade Portuguesa de Gastrenterologia Published by S. Karger AG, Basel

\section{O impacto da pandemia SARS-CoV-2 (COVID-19) na formação em gastroenterologia}

\section{Palavras Chave}

Pandemia COVID-19 · Formação · Endoscopia

$\begin{array}{ll}\text { karger@karger.com } & \text { (c) 2021 Sociedade Portuguesa de Gastrenterologia. } \\ \text { Pww.karger.com/pjg } & \begin{array}{l}\text { Published by S. Karger AG, Basel } \\ \text { This is an Open Access article licensed under the Creative Commons }\end{array} \\ \text { Karger } & \begin{array}{l}\text { Attribution-NonCommercial-4.0 International License (CC BY-NC) } \\ \text { (http://www.karger.com/Services/OpenAccessLicense), applicable to } \\ \text { the online version of the article only. Usage and distribution for com- } \\ \text { mercial purposes requires written permission. }\end{array}\end{array}$

karger@karger.com 


\section{Resumo}

Introdução: A pandemia SARS-CoV-2 (COVID-19) trouxe uma mudança radical nas nossas rotinas de trabalho. Estas mudanças afetaram a formação dos internos de gastroenterologia, em particular nas técnicas endoscópicas, uma vez que se tratam de procedimentos geradores de aerossóis. O objetivo desta pesquisa foi avaliar o efeito da pandemia COVID-19 na formação gastrenterológica em todos os países europeus. Metodologia: Foi elaborado um questionário onde foram analisados dos diferentes componentes da formação. O questionário (online) foi distribuído entre os internos de gastrenterologia através dos Representantes Nacionais do European Board de Gastroenterologia e Hepatologia. Resultados: No total, obtivemos respostas de 86 internos (mulheres: 55\%; idade média: 32,5 anos ( $\mathrm{DP} \pm 4,57$ anos); duração média de internato complementar de 2,68 anos (DP $\pm 1,63$ ), provenientes de 22 países, dos quais 10,5\% foram considerados de risco para adquirir COVID-19. Durante a sua prática clínica, $4,7 \%$ contraíram a infeção e $26,7 \%$ foram colocados em quarentena. A maioria dos internos respondeu que vários aspetos da sua formação gastrenterológica foram moderada ou gravemente afetados durante a altura inicial da pandemia: formação gastrenterológica clínica $(67,4 \%)$, consulta externa $(75,5 \%)$, formação teórica $(88,3 \%)$, reuniões multidisciplinares $(65,2 \%)$ e ensino em endoscopia (75,6\%). Mais tarde, quando o número de infeções relacionadas com COVID-19 diminuiu em toda a Europa, as atividades acima descritas voltaram à normalidade para menos de 50\% dos internos. Conclusão: Esta pesquisa em toda a Europa demonstrou que a formação dos internos em gastrenterologia foi gravemente afetada durante a fase inicial da pandemia e nos meses seguintes. Além disso, o impacto psicológico nos internos, em termos de qualidade de treino, duração e exposição ao COVID-19, é desconhecido. Deve ser realizada uma reavaliação dos programas de formação de cada centro a fim de garantir a manutenção de um elevado padrão de ensino.

○ 2020 Sociedade Portuguesa de Gastrenterologia Publicado por S. Karger AG, Basel

\section{Introduction}

The SARS-CoV-2 (COVID-19) pandemic has brought radical changes both to our daily lives and to our clinical commitments. During the period of March 2020, most of Europe was passing through the first wave of the pandemic. Across Europe the numbers decreased significant-

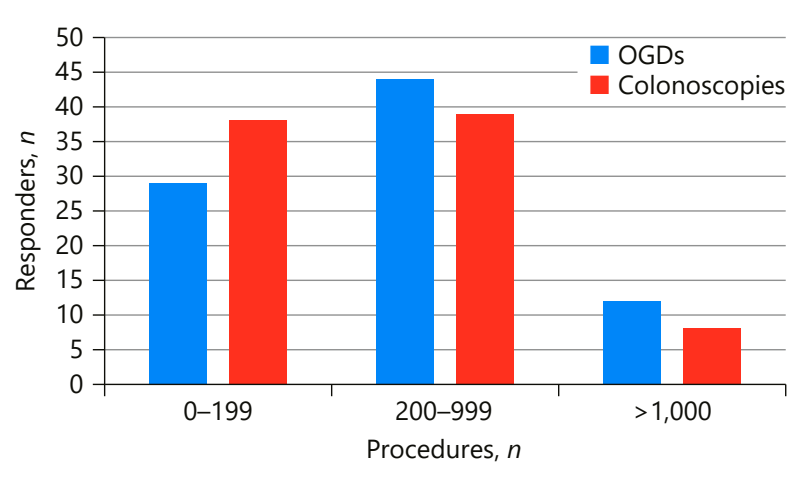

Fig. 1. Number of OGDs (oesophagogastroduodenoscopies) and colonoscopies performed by the responders.

ly during the month of June, with a return to somewhat normal daily activities and the re-introduction of air travel. From August 2020, however, we once again saw a rise in numbers of infected patients. In the current and coming months, most European countries seem to be facing another drastic increase in people infected with COVID-19 [1].

The transmission routes of the virus are through droplets, aerosol and via the faecal-oral route. Thus, apart from the routine clinical work of ward and outpatientrelated activities, the endoscopy practice puts the trainers and trainees at high risk of infection [1-3]. Most societies have issued recommendations where the main aspects were to focus on clinical service prioritization and restricted endoscopy service [4]. With time, there has been a reformulation of both the clinical, outpatient and endoscopy services. In terms of endoscopy: initially, elective procedures were postponed and it was suggested that endoscopic procedures are performed by experienced personnel. Clinical consultations were also reduced and/or temporarily withheld, and some centres moved to online or telephone consultations.

Consequently, training programmes and trainees were faced with unexpected challenges. Trainees in public health, internal medicine, intensive care medicine and respiratory and infectious diseases are being exposed to unique training opportunities which are relevant to them. For other specialties such as gastroenterology, the curtailment of outpatient services and endoscopy services may have led to redeployment of trainees. Furthermore, the pandemic scenario has led to postponement of postgraduate events. United European Gastroenterology week this 
Table 1. Effect of COVID-19 on various aspects of training during the first 3 months of the pandemic

\begin{tabular}{|c|c|c|c|c|c|}
\hline Aspect & $\begin{array}{l}\text { Not affected, } \\
\%(n)\end{array}$ & $\begin{array}{l}\text { Slightly, } \\
\%(n)\end{array}$ & $\begin{array}{l}\text { Moderately, } \\
\%(n)\end{array}$ & $\begin{array}{l}\text { Completely, } \\
\%(n)\end{array}$ & $\begin{array}{l}\text { Not applicable, } \\
\%(n)\end{array}$ \\
\hline Clinical gastroenterology training & $5.8(5)$ & $26.7(23)$ & $26.7(23)$ & $40.7(35)$ & 0 \\
\hline Gastroenterology outpatient sessions & $3.5(3)$ & $15.1(13)$ & $30.2(26)$ & $45.3(39)$ & $5.8(5)$ \\
\hline Didactic teaching/journal clubs & $1.2(1)$ & $8.1(7)$ & $20.9(18)$ & $67.4(58)$ & $2.3(2)$ \\
\hline \multicolumn{6}{|l|}{ Exposure to multidisciplinary } \\
\hline team meetings & $1.2(1)$ & $18.6(16)$ & $41.9(36)$ & $23.3(20)$ & $15.1(13)$ \\
\hline
\end{tabular}

year was online, and the European Crohn's and Colitis Organization congress has been postponed to July 2021. The European Specialty Examination in Gastroenterology and Hepatology was postponed from April 2020 to September 2020.

Thus, there could be numerous issues that could affect the gastroenterology trainees, varying from an overall decrease in clinical and endoscopic encounters, inability to progress or perform certain aspects of training such as moving to specialized units and vulnerability of the trainee or trainer, leading to the need to stop working. Furthermore, one also has to consider the overall psychological aspect of fear of exposure, or actual exposure and acquiring COVID-19.

The aim of this survey was to assess the effect of the COVID-19 pandemic on gastroenterology training across the European countries.

\section{Methodology}

A questionnaire assessing the different elements of training was set up. The questionnaire contained an introduction highlighting the rationale behind the study, its aims and a statement that all responses would remain anonymous. The questions posed addressed general demographics, deployment to other roles during COVID-19 and effect on various aspects of training during the first 3 months of the pandemic as well as after 3 months (see online suppl. file 1, see www.karger.com/doi/10.1159/000515408). A description of the survey highlighting the aims, estimated time to complete the survey and reassurance of confidentiality, together with the link to the questionnaire, was sent via e-mail to the National Representatives of the European Board of Gastroenterology and Hepatology who in turn send it to their trainees. The e-mail was sent 3 times (August, September and October 2020) as to increase the response rate. A description of the survey and a link to the questionnaire was also posted 3 times on the Facebook page "Young GI Network" which is a public group associated with United European Gastroenterology. The data were automatically put into a database (Microsoft Office Excel ${ }^{\circledR}$ ) and analysed.

Assessing the Impact of the COVID-19

Pandemic on Gastroenterology Training

\section{Results}

One hundred and twenty-four responses were collected through the questionnaire. Of these 38 were not trainees and thus were not included in the final analysis. In total, 86 trainees from 22 different countries were recruited, of whom $55.8 \%$ were females. The mean cohort age was 32.5 years ( $S D \pm 4.57$ years) and their mean duration of training was 2.68 years ( $S D \pm 1.63$ ). Figure 1 demonstrates their endoscopy experience prior to the pandemic.

There was $10.5 \%$ of the cohort which was deemed to be vulnerable (for varying reasons, as defined by the specific country) for acquiring COVID-19. During their job, $4.7 \%$ of the cohort acquired the infection, and $26.7 \%$ were placed in quarantine because of exposure to COVID-19.

Seventy-one percent of the trainees' job changed significantly during the pandemic with approximately a quarter (24.4\%) being moved into seeing only COVID-19 patients and $45.3 \%$ of the cohort assigned tasks that they do not usually perform. Only $5.8 \%$ replied that their clinical work was not affected whilst $23.3 \%$ reported that it was slightly affected (Table 1 ).

During the first 3 months of the pandemic, the greatest impact of COVID-19 was on didactic teaching, with $88.3 \%$ reporting that it was either completely or moderately affected. Three quarters of respondents reported significant influence on their attendance at gastroenterology outpatient sessions (75.5\%) and endoscopy training (75.3\%), while $65.5 \%$ had a decreased exposure to multidisciplinary meetings (MDT; Table 1). Regarding online platforms, $48.8 \%$ reported that their unit moved to online teaching, and $40.7 \%$ stated that their MDTs were being carried out virtually.

The main reasons for the reduction in the number of procedures performed by the trainees were both due to the hospital policy to decrease the number of patients attending the hospital as well as the patients' fear of attend- 
Table 2. Reasons for a lower endoscopy exposure

\begin{tabular}{lcc}
\hline & $\begin{array}{l}\text { Initial effect, } \\
\%(n)\end{array}$ & $\begin{array}{l}\text { After 3 } \\
\text { months, \% }(n)\end{array}$ \\
\hline Hospital policies prohibiting trainees from performing endoscopy & $20.9(18)$ & $16.3(14)$ \\
Hospital policy decreasing number of procedures & $78.0(67)$ & $63.9(55)$ \\
Fewer patients attending endoscopy & $31.4(27)$ & $32.6(28)$ \\
Trainer's personal choice & $5.8(5)$ & $8.1(7)$ \\
Assigned other work & $7.0(6)$ & $2.3(2)$ \\
Personal choice/reasons & $1.2(1)$ & $2.3(2)$ \\
\hline
\end{tabular}

Table 3. Resumption of clinical training 3 months into the pandemic

\begin{tabular}{|c|c|c|c|c|c|c|}
\hline Aspect & $\begin{array}{l}\text { Normal, } \\
\%(n)\end{array}$ & $\begin{array}{l}\text { Reduced by } \\
20 \% \text {, } \\
\%(n)\end{array}$ & $\begin{array}{l}\text { Reduced by } \\
20-50 \% \text {, } \\
\%(n)\end{array}$ & $\begin{array}{l}\text { Reduced by } \\
50-80 \% \text {, } \\
\%(n)\end{array}$ & $\begin{array}{l}\text { Reduced by } \\
>80 \% \text {, } \\
\%(n)\end{array}$ & $\begin{array}{l}\text { Not applicable, } \\
\%(n)\end{array}$ \\
\hline Clinical gastroenterology training & $47.7(41)$ & $27.9(24)$ & $14(12)$ & $5.8(5)$ & $4.7(4)$ & \\
\hline Gastroenterology outpatient sessions & $48.8(42)$ & $20.9(18)$ & $10.5(9)$ & $8.1(7)$ & $4.7(4)$ & $7(6)$ \\
\hline Didactic teaching/journal clubs & $43.3(37)$ & $10.5(9)$ & $7(6)$ & $16.3(14)$ & $17.4(15)$ & $5.8(5)$ \\
\hline \multicolumn{7}{|l|}{ Exposure to multidisciplinary } \\
\hline team meetings & $0.7(35)$ & $11.6(10)$ & $4.7(4)$ & $9.3(8)$ & $9.3(8)$ & $24.4(21)$ \\
\hline Endoscopy training & $41.9(36)$ & $23.3(20)$ & $14(12)$ & $8.1(7)$ & $7(6)$ & $5.8(5)$ \\
\hline
\end{tabular}

ing hospital (Table 2). Though the endoscopy exposure decreased, only $14 \%$ had the opportunity to use endoscopy simulators during this time. This has affected the trainee confidence in performing procedures to various extents, with trainees stating that this had either slightly $(27.9 \%)$, moderately $(23.3 \%)$ or severely affected their confidence (7\%). However, $41.9 \%$ stated this did not affect their confidence at all.

Three months into the pandemic, $47.7 \%$ of trainees reported that their clinical gastroenterology training returned to normal, $41.9 \%$ said that it had been reduced by less than half and $10.5 \%$ stated it had been reduced by more than half (Table 3 ). The aspect to have returned to normal in most trainees was attendance to gastroenterology outpatients $(48.8 \%)$. Didactic teaching had still not improved, with $33.7 \%$ reporting that it had been reduced by $50 \%$ or more. With regard to endoscopy and exposure to MDTs, 15.1 and $18.6 \%$, respectively, of trainees stated that they were reduced by $50 \%$ (Table 3 ).

Half $(50.6 \%)$ of the trainees who replied were performing research prior to COVID-19. Of these, $67.4 \%$ had to stop or reduce their research during the pandemic and after 3 months, $60.5 \%$ were able to return to normal. The medium-term impact of this pandemic was also assessed with $30.2 \%$ stating that their duration of training will be increased, $20.9 \%$ had fellowships postponed and $30.2 \%$ had relevant gastroenterology examinations postponed. Regarding progression, $15.1 \%$ were planning on taking up a specialist post that was delayed or postponed while $8.1 \%$ were aiming for a post that was no longer being offered.

\section{Discussion}

This European-wide survey on how this pandemic has impacted gastroenterology training across the European countries demonstrates that GI training has been affected to various extents and encompasses all aspects - clinical, endoscopy, MDT meeting exposure, examinations and research. This is somewhat similar in terms of service curtailment to the British Society of Gastroenterology survey among all its members which however included specialists [5]. Thus, over the coming months trainees might continue to experience similar limitations to their training. From the above results, it has been demonstrated that the training was affected to various extents during the first wave of the pandemic, with respondents replying that their training was moderately to severely affected across the various aspects of training, these being: clinical gastroenterology training (67.4\%), outpatient $(75.5 \%)$ didactic teaching (88.3\%), MDT meeting (65.2\%) and en- 
doscopy training (75.6\%). Of more concern is the fact that when the number of COVID-19-related infections decreased across Europe, the above modalities returned to normal for less than $50 \%$ of the trainees.

Didactic teaching was the aspect most strongly affected. This could be due to trainers having less time for teaching, trainees not having the opportunity to attend lectures and reluctance for all trainees to meet in one room. Online learning is not a new concept, and several societies have been offering online courses and lectures even before the pandemic [6]. In a hospital setting, however, not all trainers might have the necessary apparatus, setting and know-how to deliver online lectures. Financial investment and upgrades in hardware and/or software might be needed in a time when resources are being directed elsewhere.

This survey gains more importance as once again we are seeing an increased number of COVID-19 infections across Europe. The failure to achieve the required skills within the time schedule has to be addressed. This may imply both a pre-empting of extension of training time as well as restructuring of the programme. Reasons for restructuring of the training programme include changes in the amount of exposure to gastroenterology training as well as new realities such as the introduction of online phone/video consultations. This particular topic has not been addressed in the questionnaire as it is an evolving topic that has already been discussed elsewhere [7]. One has to question whether remote consultations have the same learning value as face-to-face consultations. Trainees not only have to consider the clinical question posed by the consultation; they also have to decide whether a physical examination is required. It also changes the concept of the usual supervised training in clinics. Thus, young trainees should be taught how to obtain reliable clinical data through online consultations.

In terms of training extension our results already demonstrate that this has already happened in some centres as $30.2 \%$ of trainees noted that their training duration has been increased. The postponement of relevant gastroenterology examinations may also result in training extension as in some countries this would be a requirement for completion of training. Furthermore, the fact that $20.9 \%$ had fellowships postponed might lead to delay in training as well as the loss of acquisition of new skills among our future gastroenterologists.

Another aspect which would also need to be addressed is the psychological aspect of our trainees. Being listed as vulnerable for acquiring the infection can have psychological implications both in terms of training duration as

Assessing the Impact of the COVID-19

Pandemic on Gastroenterology Training well as in terms of health concerns and the implications of acquiring the infection. This is demonstrated by the fact that $4.7 \%$ of our cohort acquired the infection and $26.7 \%$ were placed in quarantine. Thus, such events can have implications both in terms of training duration as well as psychological stress [8].

On a positive note, the trainees' accessibility to European gastroenterology conferences has remained there and possibly has become more accessible as these have gone both online and their prices have been reduced. Thus, the lower cost for the conference registration as well as the absence of travelling and accommodation costs should make such resources more readily accessible to all trainees and should also be considered and continued once the pandemic is over.

A strength of the study was the participants' range of countries and their different levels of expertise. A limitation is the relatively small cohort and the possibility of response bias. Respondents could have been more affected than those who opted not to respond. It is interesting to note that most trainees who replied were in the midpart of the training programme. This could be that they were more severely affected and more concerned about their training. Such trainees might not have been independent in doing endoscopies and might have been more concerned with regard to having adequate time in achieving the required competences within the training programme's time frame. This could delay their gastroenterology accreditation.

In conclusion these are difficult times ahead, and a training analysis will need to be done by each training centre in order to identify new lacunae in training, both in terms of quantity and quality. Improvements could include using online platforms for MDTs, increased use of simulators during endoscopy, organizing targeted training and utilizing alternative methods for didactic teaching. Furthermore, the psychological impact of all this on our trainees should also be taken care of. Our main aim as specialists is to defend the trainee's interest and provide the best and safest environment and resources for training as these are both our future gastroenterologists and trainers.

\section{Statement of Ethics}

This research is in conformity with the University of Malta's Research Code of Practice and Research Ethics Review Procedures, approval code: 8248_01042021_Anthea Pisani.

The study was disseminated via email and social platforms and participation was on a voluntary basis. Participants were informed 
the responses would be anonymous and no identifiable data was collected. Participants were informed of the aims of the study. Written consent was not obtained as consent was implied by the fact that participants opted to fill in the survey. No data from persons under 18 or persons who are vulnerable was collected.

\section{Conflict of Interest Statement}

The authors have no conflicts of interest to declare.

\section{Funding Sources}

There are no funding sources to declare.

\section{Author Contributions}

Anthea Pisani designed the survey, assisted with data acquisition, interpreted the data, assisted with the drafting of the paper and has reviewed the final version and approves its publication. Isabelle Cremers assisted with data acquisition, revised the survey and the paper and has reviewed the final version and approves its publication. Pierre Ellul conceptualized the study, assisted with data acquisition and data interpretation, drafted the paper and has reviewed the final version and approves its publication.

\section{References}

1 European Centre for Disease Prevention and Control. Download the daily number of new reported cases of COVID-19 by country worldwide, ecdc.europa.eu, 2020 [cited 2020 Nov 14]. Available from: https://www.ecdc. europa.eu/en/publications-data/downloadtodays-data-geographic-distribution-covid19-cases-worldwide

2 Repici A, Maselli R, Colombo M, Gabbiadini R, Spadaccini M, Anderloni A, et al. Coronavirus (COVID-19) outbreak: what the department of endoscopy should know. Gastrointest Endosc. 2020 Jul;92(1):192-7.
3 Colégio da Especialidade de Gastrenterologia da Ordem dos Médicos e Sociedades Portuguesas de Endoscopia Digestiva e Gastrenterologia. Organização dos Serviços de Gastrenterologia na era COVID-19 - Comunicado conjunto. 2020.

4 Gralnek IM, Hassan C, Beilenhoff U, Antonelli G, Ebigbo A, Pellisè M, et al. ESGE and ESGENA position statement on gastrointestinal endoscopy and the COVID-19 pandemic. Endoscopy. 2020 Jun;52(6):483-90.

5 The British Society of Gastroenterology. Survey results: the effect of COVID-19 on gastroenterology [cited 2020 Nov 14]. Available from: https://www.bsg.org.uk/workforce-reports/the-effect-of-covid-19-on-gastroenterology/
6 Cook DA, Dupras DM. A practical guide to developing effective web-based learning. J General Internal Med. 2004 Jun;19(6):698707.

7 Keihanian T, Sharma P, Goyal J, Sussman DA, Girotra M. Telehealth utilization in gastroenterology clinics amid the COVID-19 pandemic: impact on clinical practice and gastroenterology training. Gastroenterology. 2020 Oct;159(4):1598-601.

8 Abbas AM, et al. Psychological effect of COVID-19 on medical health-care workers. Int J Psychiatry Clin Pract. Epub 2020 Jul 15. 